\title{
Small Business Attitudes Towards Ethical Issues: Survival Or Ethically Correct?
}

\author{
Michael Colin Cant, Ph.D., University of South Africa, South Africa
}

\begin{abstract}
Small businesses play a vital role in most economies worldwide. These businesses are in many instances the creators of jobs and in many instances barely surviving. In Africa, in general, and South Africa in particular, there are huge pressures on small business development and to assist in alleviating poverty and help with social mobility. Many small business entrepreneurs are forced into business in order to survive which in turn may lead to them being less ethically inclined and more focussed on survival. This in itself can lead to a moral dilemma for them. It is therefore important to consider the attitude employees have towards ethical issues in the business sector, and to what extent they would compromise on these issues in order to survive. The main purpose of the study is therefore to determine the attitude employees of small businesses in South Africa have towards the ethical environment in which they operate. The research followed a quantitative approach where a survey questionnaire was used as the data collection method. The results indicate that employees of small businesses have a negative attitude towards the ethical responsibilities of the organisation in which they operate. Alternatively, respondents do understand what is meant by ethics and what it entails. Their attitude regarding their perception of what an organisation should commit to in order to be ethical shows that respondents understands what constitutes ethical behaviour.
\end{abstract}

Keywords: SMEs; South Africa; Ethical Behavior; Ethical Issues; Ethical Environment; Attitude

\section{INTRODUCTION}

Q

ince the great collapse of the major banks in Europe and the USA in 2008and the uncovering of major corruption in many organisations and businesses there has been a strong focus on ethics and ethical behaviour of companies. Small businesses in particularly are not exempt from this and in many instances follow the lead of larger organisations. Reported cases of ethical misconduct in small businesses include bribery, exploitation, violations of human rights, sexual harassment and theft amongst employees and management (Asgary \& Mitschow, 2002; St James Ethical Centre, 2009). Therefore, ethical concerns also emerge in small businesses and their attitudes towards ethical misconduct and behaviours cannot be ignored.

The small business sector plays a vital role in economic development in all countries and has become the primary building block of job creation in the Republic of South Africa (Valadez, 2011:1; Wielicki \& Arendt, 2010:162). Consequently, operating in today's complex business environment can be challenging and stressful for small businesses to survive. This can have a negative effect on the way they conduct business to be profitable; in other words, whether the survival of small businesses are more important than operating ethically. The goal of the ethical environment, as stated by Raisner (1997:1331) and Yang (2006:23), is ultimately to rationalise moral motivations and beliefs for the purpose of protecting the global environment. Mahdavi (2009:2) observed that, with the expansion of global businesses, the study of ethics has become gradually more important, due to the increase in ethical and social responsibility. Rao and Vitell (2003:133) identified the most important reason for examining ethical issues as being that, business ethics is not simply an addition of an individual's own personal ethics. Many believe that if an organisation employs people with solid ethical values, then it will be a "good citizen" organisation - but this is not necessarily the case. 
Limited research was conducted regarding employees' attitude towards the ethical business environment; therefore the aim of this study was to investigate the attitude employees of small businesses in South Africa have towards the ethical environment in which they operate today. In the subsequent section of the study, the objectives and hypotheses will be provided. The research methodology used to conduct this study will then be discussed followed by a review of the available literature. The research findings, recommendations and concluding remarks will then conclude the study.

\section{RESEARCH OBJECTIVES}

The aim of this research was to investigate the attitude employees of small businesses have towards the ethical environment of the business sector in South Africa. Secondary objectives of the study comprises of the following:

- $\quad$ To investigate whether small business employees understand what ethical behaviour/conduct involves.

- To determine the attitude employees have towards the ethical responsibilities of the business.

- To investigate the attitude employees have regarding the commitments the organisation should make to act ethically.

\section{RESEARCH METHODOLOGY}

In order to establish the attitude employees have regarding the ethical environment of small businesses, the research followed a quantitative analysis and the data collection instrument that was used was a survey questionnaire. Secondary as well as primary data were used to obtain information in order to analyse the attitude employees of small businesses have towards the ethical environment. To address the problem adequately, the research methodology was based on the primary data collected between the $25^{\text {th }}$ of April 2012 and $10^{\text {th }}$ of May 2012, from employees/owners of small businesses. The population for the research survey consisted of employees from small businesses in the Tshwane region of South Africa. The sample comprised of 24 employees from micro-sized businesses and 21 employees from small businesses for a total sample size of 45 respondents. Convenience sampling was used as the sampling method for this study due to the fact that it is the most effective method to gather questionnaires in a short period of time (Zikmund \& Babin, 2007:273).

The questionnaire comprised of a set of two 7-point Likert-scale questions that were used to determine the main constructs of this study. The first section examined the attitude employees of small businesses display towards the ethical responsibilities of a small business, while the second section investigated the attitude small business employees have towards the commitments the business should make in order the act ethically in the business environment. The last section of the questionnaire comprise of the demographic and socio-economic attributes, which described the profile of the respondents.

\section{ETHICS AND THE BUSINESS ENVIRONMENT}

As recently as 10 years ago very few people or companies were really concerned about ethical issues and ethical behaviour. Most only focussed on lip service to these issues but this has changed dramatically as the business environment has changed in the past few years. The ethical environment is therefore a relatively new subdiscipline with the intention to rationalise moral motivations and beliefs for the purpose of environmental protection (Raisner, 1997:1331; Yang, 2006:23). Business ethics can be defined as recognising and implementing commonly agreed upon standards of conduct that ensures that the company will not impact its stakeholders negatively. In other words, business ethics is what is regarded as right and wrong or good and bad human behaviour in the business environment (Shakeel, Khan, \& Khan, 2011:59; Shaw, 2002:4). These commonly agreed upon standards and issues being regarded as being good or bad will differ from person to person and company to company and is influenced by a wide range of factors such as culture, background, and reference groups. Today's challenge for business leaders is to be profitability while still conducting business in a way that is ethically acceptable in the broader business environment. Consequently all organisations, big or small, must ensure that they conduct business in an ethical manner and not ignore these ethical issues. 


\section{Attitude towards ethical responsibility}

Business ethics have received considerable attention in recent years in both organisational and academic spheres. The majority of ethical attitude studies focused mainly on the comparisons of the perception and attitude of business ethics across different groups or countries (Bageac, Furrer \& Reynaud, 2011:391; Collins, Dickie \& Weber, 2010:85; Gao, 2008:153; Ibrahim, Angelidis \& Tomic, 2009:343; Quinn, 1997:119). These studies have indicated that there is a significant difference in the attitude of the groups researched and the countries in terms of what is regarded as being ethical and what not. Vitell, Dickerson and Festervand (2000:15) conducted a study investigating the beliefs and perceptions of small business professionals concerning ethics within their company and business in general. The results have indicated that there is an increase in small business professionals tend to believe that ethical standards in businesses are lower today than those that belief they have increased than ten or twenty years ago. The most important factor that have been cited as to the lowering of standards is the changing in society's standards as a whole, and personal greed was also noted as a significant factor (Vitell et al., 2000: 22).

Limited academic research has however been conducted regarding the attitude employees of small businesses have towards the ethical environment within the business sector. The most recent academic study regarding ethics was conducted by Price and van der Walt (2012), who investigated whether the attitudes that former South African business management students had towards business ethics have changed between the 1990s and 2010. Their research concluded that the attitudes towards business ethics have changed significantly, but negatively, over the past few years. This can be regarded as negative due to the fact that the economical landscape of South Africa has changed significantly over the ten years, from the time they were in political and cultural turmoil to the current economic realities (Price \& van der Walt, 2012:10).

A study by the St. James Ethical Centre (2009) regarding the attitude that employees can have towards the ethical environment, found that more than eighty percent of the respondents indicated the following issues as what they believe business ethics entails:

- $\quad$ acting with integrity towards the individuals the organisations serves;

- $\quad$ treating the companies employees well and with respect;

- $\quad$ respecting everybody's' fundamental human rights;

- $\quad$ conducting business according to the values and beliefs of the organisation;

- $\quad$ making a profit is not the most important thing in business; and

- $\quad$ being environmentally responsible.

These issues can be seen as indicative of the attitudes towards ethics and as such are used in this study to determine the attitude employees of small businesses in South Africa have towards the ethical environment of the business sector and what they belief constitutes an ethical environment.

\section{Business and individual commitments to be ethical}

The factors that influences and affects an individual's attitude and behaviour towards ethics are complex and multi-dimensional. This in effect means that there will in all probability be differences between individuals and the business environment, but that there exists a relationship between these two as well (Longenecker, Moore, Petty, Palich \& McKinney, 2005:7).This relationship implies that the ethical behaviour and the perception towards ethics is not formulated from the morals and beliefs of individuals on its own but rather s a result of the interaction with these external factors in the business environment. Businesses in many instances state that their ethical commitments range from treating employees well, to benefiting the community and being ethically responsible - much the same as individuals do. It is also a known fact that even the most loyal employees in a business can find that their own self interests are in conflict with the interests of the organisations. This is referred to as conflict of interest, which is defined by Shaw (2002:280) as a morally risky situation and should be avoided by employees.

In all businesses the employees as well as the management team take responsibility for the ethics in their working environment. Due to adverse economic conditions and high unemployment it is more difficult for people to wait for a job which fits their moral standards as many people are about earning a living first and then about morals 
and ethics. In these conditions people do not have the luxury of waiting around for the "perfect" job (Rossow, 2004:3). In spite of this however employees generally have a very high ethical expectation from businesses and other organisations they are in contact with. The study conducted by the St. James Ethical Centre (2009) has indicated that the following factors are important considerations, from the perception of the employees, for organisation to act ethically in the way they conduct business:

- Even if acting ethically harms the profit of the organisation, businesses are still obligated to act ethically.

- $\quad$ Business owners should make an official promise to act ethically.

- $\quad$ In order for businesses to comply with their code of ethics, their ethical performance should be measured and reports made available.

- $\quad$ Business in a specific country (i.e. South Africa) is done much more ethically than a few years ago.

- When operating in a foreign country, it is acceptable for a business to follow the ethical code of that country, even if it disagrees with the ethical code of the business.

Factors determining employee's attitudes towards the commitments they have to make towards the organisation to act ethically can be influenced by a number of measures. These include the following (St. James Ethical Centre, 2009):

- $\quad$ Employees are generally willing to put extra effort into their work if they know their organisation is run ethically.

- $\quad$ Employees usually have a personal code of ethics they adhere to and would risk their job to protect or adhere to their ethics if the organisation is not operated according to their ethical beliefs.

- $\quad$ Employees want the organisation they work at to have a comprehensible and understandable code of ethics that is easy to follow.

- $\quad$ Employees might consider resigning from the organisation if they cannot reconcile their ethics with those of the organisation

It is evident that there are various commitments the organisation as well as the employee has to make in order to operate ethically in the environment in which businesses operate and that the marriage between the personal ethics and the organisational ethics are central to this dilemma. The study therefore aims to investigate small business employees' attitudes towards the commitment and promises the organisation has to make in order to be ethical in its operations and dealings.

\section{RESEARCH FINDINGS}

The population for the research survey consisted of 45 small business employees and owners in the Tshwane region of South Africa. According to a study compiled by World Wide Worx (2012:9), there are 650000 active registered small businesses in South Africa, contributing approximately 55percent to the total GDP and providing about 61 percent of the country's employment. Although the sample size (45) do not represent the entire small business population of South Africa, it is sufficient to provide a holistic approach to the attitude these employees have towards the ethical business environment of South Africa. The following research findings were observed in the study.

\section{Self-employed or employed by a business}

Respondents were asked to indicate whether they are employed by an organisation or self-employed, in other words, owning their own small business. Results indicated that 93 percent of the respondents own their own small business and 7 percent of the respondents indicated that they are employed by a small business. 


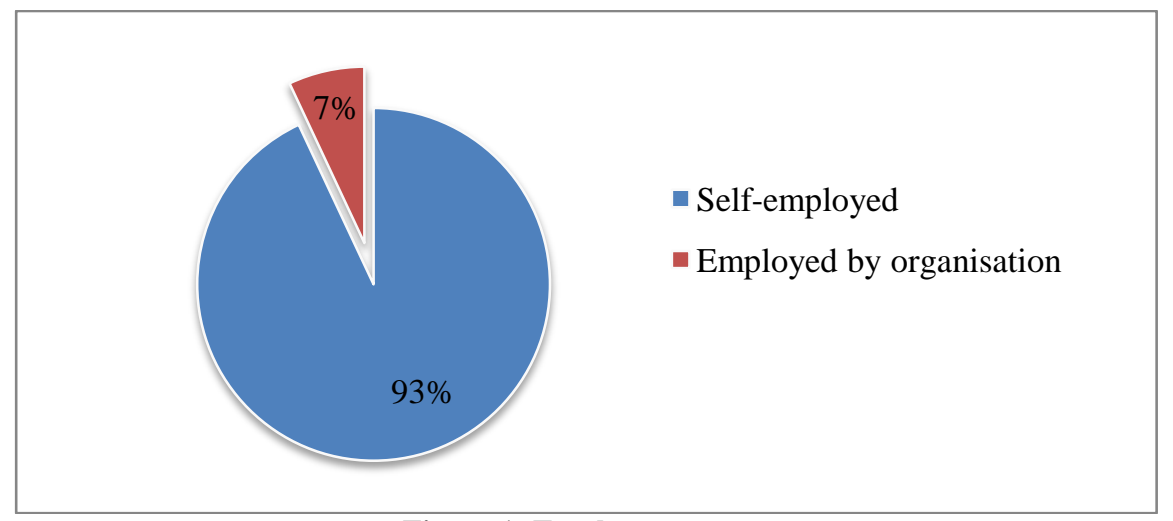

Figure 1: Employment type

\section{Attitude towards the ethical responsibilities of the organisation}

This question in the survey was in the form of a 7-item Likert scale. Respondents were asked in this question to indicate how strongly they either agree or disagree with each statement regarding their beliefs of what they regard as ethical responsible behaviour by the organisation and thereby indicating whether they understand what ethics involves or not.

The mean, according to Saunders, Lewis and Thornhill (2007) is the most frequently used measure of central tendency is the mean or average. The mean is computed by adding a list of scores and dividing them by the total number of scores (Wellman, Kruger \& Mitchell, 2007). Standard deviation is the most commonly used and most important measure of variability in statistics. According to Gravetter and Wellnaue (2009), the standard deviation uses the mean as reference point and measures variability by calculating the distance between each score and the mean. Table 1 depicts the mean scores and standard deviation of the attitude small business employees have towards the ethical responsibilities of the organisation.

Table 1: Attitude towards the ethical responsibilities of organisations*

\begin{tabular}{|l|c|c|c|c|c|c|c|c|c|c|}
\hline & $\mathbf{2 . 1}$ & $\mathbf{2 . 2}$ & $\mathbf{2 . 3}$ & $\mathbf{2 . 4}$ & $\mathbf{2 . 5}$ & $\mathbf{2 . 6}$ & $\mathbf{2 . 7}$ & $\mathbf{2 . 8}$ & $\mathbf{2 . 9}$ & Total \\
\hline Mean & 6.311 & 1.533 & 6.222 & 3.044 & 1.244 & 1.133 & 5.489 & 5.422 & 3.867 & $\mathbf{3 . 8 0 7}$ \\
\hline St. Deviation & 0.821 & 1.179 & 0.471 & 2.142 & 0.529 & 0.757 & 1.058 & 1.559 & 1.791 & $\mathbf{1 . 1 4 5}$ \\
\hline
\end{tabular}

* Measurement was done on a 7-point Likert scale, whereby $1=$ Strongly disagree and 7 = Strongly agree.

From Table 1 it can be seen that the highest degree of agreement was for statement 1, "acting honestly towards those individuals the organisation serves is ethical" (Mean $=6.311$ ). This is followed by statement 3 , "following basic human rights is good business" (Mean = 6.222) and then statement7, "acting in a way that is positive for the people the organisation serve is good business" (Mean $=5.489)$. The lowest degree of agreement was found to have come from statement 6, "doing harm to the people the organisation serve is good" (Mean $=$ 1.133). The standard deviation for statement 3 and 7 is high, indicating a large distribution of value in the question.

From all the statements that were asked, the general attitude employees of small business establishments have towards the ethical responsibilities of the organisation can be seen to be positive in nature, with a total mean score of 3.807 and standard deviation of 1.145. Figure 2 is thus indicative as to these statements and graphically presents the degree of agreeability and disagreeability. 


\section{Ethical responsiblities of organisations}

$\square$ Strongly disagree $\quad$ Disagree $\quad$ Slightly Disagree $\quad \square$ Slightly Agree $\quad$ Agree $\square$ Strongly agree

2.9. Choosing only to work with people who have the same values and principles as you is good business.

2.8. Good business is always making a profit.

2.7. Acting in a way that is positive for the people the organisation serve is good business.

2.6. Doing harm to the people the organisation serve is good.

2.5. Doing work according to the org's values is not right.

2.4. Being ethical requires one to be environmentally friendly.

2.3. Following the basic human rights is good business.

2.2. Treating employees well is NOT good business.

2.1. Acting honestly towards the individuals the organisation serves is ethical.

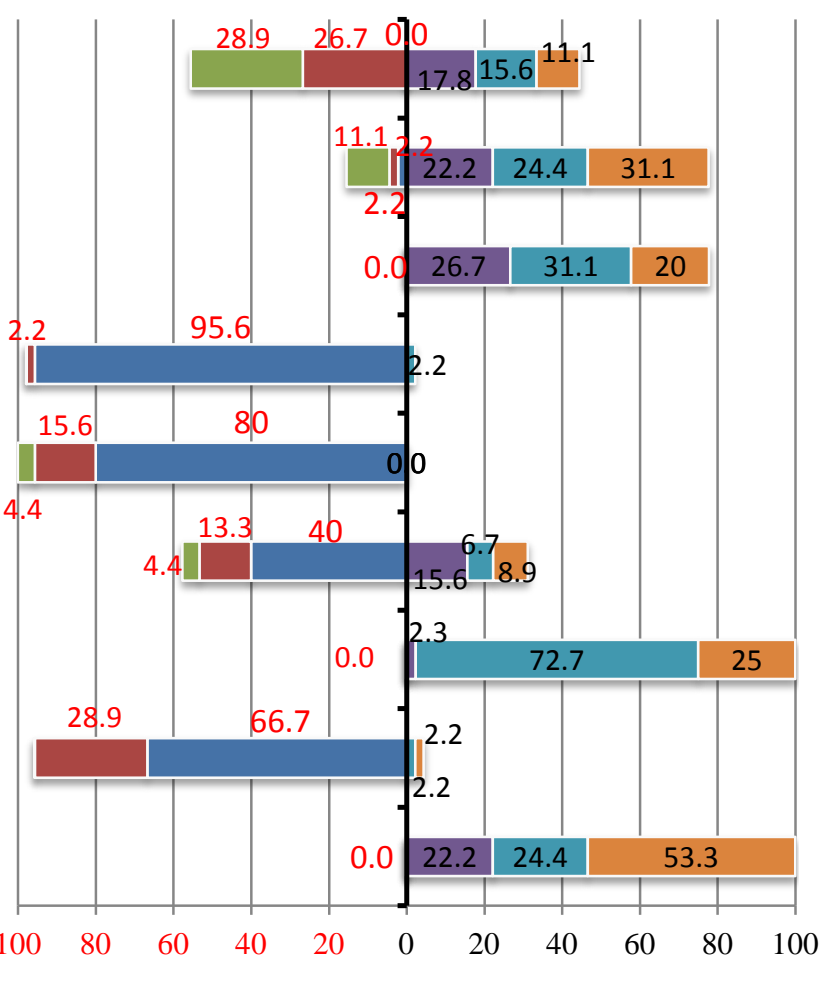

Figure 2: Attitude towards the ethical responsibilities of organisations

The majority of respondents agreed with the statement that ethics entails acting honestly towards others $(100 \%)$ and that ethics is about following the basic human rights (100\%). It is also evident from Figure 2 that respondents agree that, acting in a way that is positive for the people the organisation serve is ethical $(77.8 \%)$ and that making a profit is good business $(77.7 \%)$. A mere $15.5 \%$ of the respondents stated that always making a profit is not necessarily good business. Alternatively, respondents (95.6\%) disagree that it is not ethical to treat employees well, in other words, respondents believe that being ethical means to treat people well. Respondents also disagreed with the statement that conducting work according to the organisation's values and beliefs are not good ethical business (100\%) and 97.8 percent of the respondents disagreed that doing harm to other people is not ethical.

Employees of small businesses are aware that being ethical means being honest to the people the business serve and treating people with respect, according to the basic human rights. Respondents (57.7\%) have indicated that being ethical does not mean being environmentally friendly. However, Ferrell, Hirt and Ferrell (2012:58) stated that more people are demanding that businesses take a greater responsibility for their actions and how they affect the surrounding environment. Consequently, being ethical also entails one being environmentally sustainable.

Although respondents understand the basic fundamentals of ethical conduct, 77.7 percent agree that good business is about being profitable, indicating that making a profit is more important for these employees than operating in an ethical manner. This can be due to the complex and competitive business environment in which small businesses find themselves today as well as the fact that having a job in these difficult times are more important. These findings also contradict with respondents attitudes towards acting in a way that is positive for the people the organisation serves. Respondents agree with this statement, but also agree that an organisation should do everything in its power to be profitable. 


\section{Organisational Commitments}

In this 7-point Likert-scale question, respondents were asked to rate five statements. These statements attempted to determine the commitment organisations have to make in order to operate ethically. Respondents had to indicate whether they strongly agree or disagree with each of these statements.

Table 2depicts the mean scores and standard deviation of perception employees have of the commitments the organisations have to make in order to act ethically in the business sector.

Table 2: Attitude towards the ethical responsibilities of organisations*

\begin{tabular}{|l|c|c|c|c|c|c|}
\hline & $\mathbf{3 . 1}$ & $\mathbf{3 . 2}$ & $\mathbf{3 . 3}$ & $\mathbf{3 . 4}$ & $\mathbf{3 . 5}$ & Total \\
\hline Mean & 4.333 & 4.311 & 2.467 & 4.089 & 4.400 & $\mathbf{3 . 9 2 0}$ \\
\hline St. Deviation & 1.665 & 2.065 & 1.854 & 1.649 & 1.629 & $\mathbf{1 . 7 7 2}$ \\
\hline
\end{tabular}

$*$ Measurement was done on a 7-point Likert scale, where $1=$ Strongly disagree and $7=$ Strongly agree.

From Table 2 it can be seen that the highest degree of agreement was for statement 5 , "to be ethical, an organisation does not have to be transparent in the way they do business" (Mean $=4.4$ ). This is followed by statement 1, "organisations have a responsibility to act ethically, even if it harms their profit" (Mean $=4.333$ ). The lowest degree of achievement was found to have come from statement 3, "business in South Africa is done much more ethically than before" (Mean $=2.467$ ). The standard deviation for statement 2 and 3 is relatively high, indicating a large distribution of value in the question.

From all the statements that were asked, the general attitude employees of small business establishments have towards the commitments organisations have to make to be ethically in the way they conduct business, with a total mean score of 3.920 and a total standard deviation of 1.772. Figure 3 is thus indicative as to this statement and graphically presents the degree of agreeability and disagreeability.

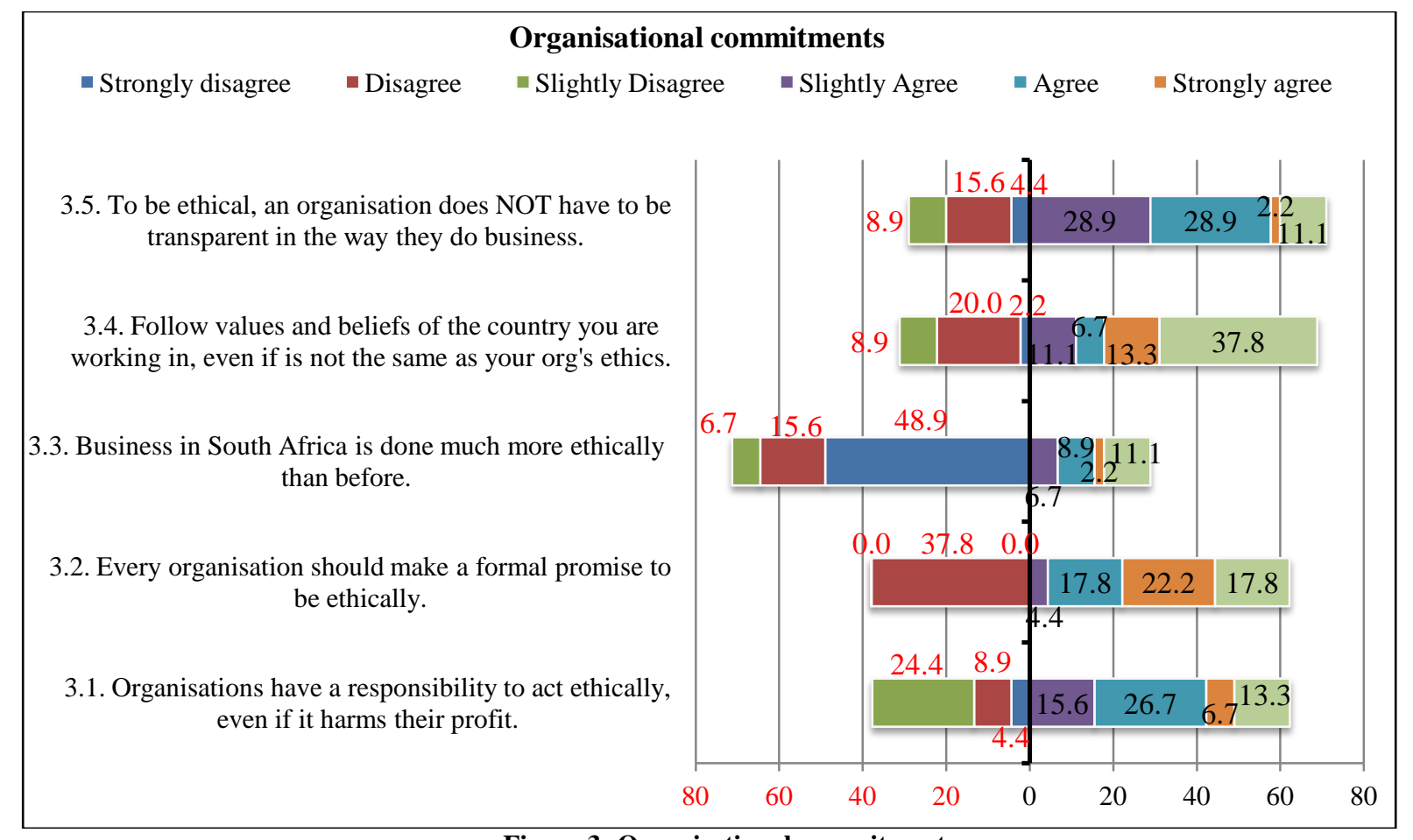

Figure 3: Organisational commitments

Figure 3 illustrates respondents attitude towards the commitments or promises organisations have to make in order to be ethical in the way they conduct business. Respondents $(71.2 \%)$ disagreed with the statement that 
business in South Africa is conducted more ethically than before. This observation is significant as it lays the foundation for their own perceptions as to what is ethical and what is not. The fact that there are daily reports of corruption, bribery, fraud and other unethical behaviour by senior government and large business people, will influence their perception of what is ethical and what not. This attitude can be due to the increase in the crime rate, fraud in larger more profitable organisation and the widespread corruption in the government and this might be indicative of respondents having low moral values. Alternatively, opposed to the perception respondents have towards the current situation of the ethical business environment, respondents have indicated that one should work according to the values and beliefs of the organisation, even though it might not be ethically correct.

Interestingly, respondents $(71.1 \%)$ agreed that an organisation does not have to be transparent to be ethical. Respondents (62.2\%) also agreed that organisations should have a formal promise to act ethical and 62.3 percent agreed that an organisation should act ethically, even if it means not making a profit. This contradicts with their attitudes towards previous statements in the questionnaire, such as agreeing that acting honestly is good business and an organisation should make a formal promise to act ethically.

\section{Demographic profile of respondents}

Lastly, respondents were asked to indicate their socio-economic and demographic information for the purpose of the study. Questions such as the respondents occupational level, gender, age and racial group were asked in the demographics section of the questionnaire. The following information were gathered from the respondents and used to establish the demographic profile of respondents who participated in the study.

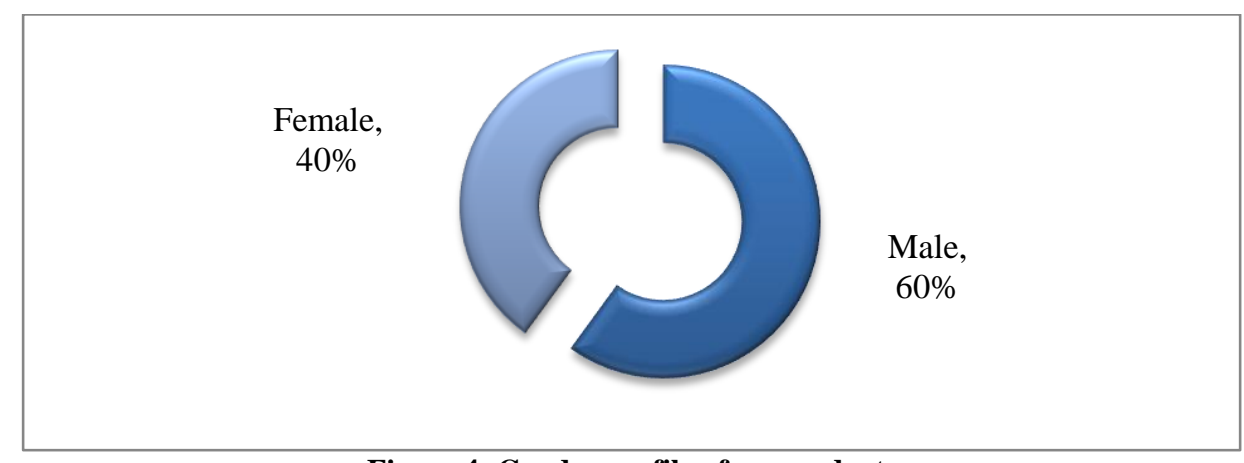

Figure 4: Gender profile of respondents

The sample consisted of 60 percent (or 27) male respondents and 40 percent (or 18) female respondents, as illustrated in Figure 4. Figure 5 illustrates the age distribution of the respondents who participated in the study. The majority of the respondents were between the age of 26 and 35 (42\%) and 19 to 25 (40\%). Sixteen percent of the sample consisted of respondents between the age of 36 and 45 and only 2 percent were older than 56 years of age. No respondents who participated in the study were younger than 18 or between the age of 46 and 55 .

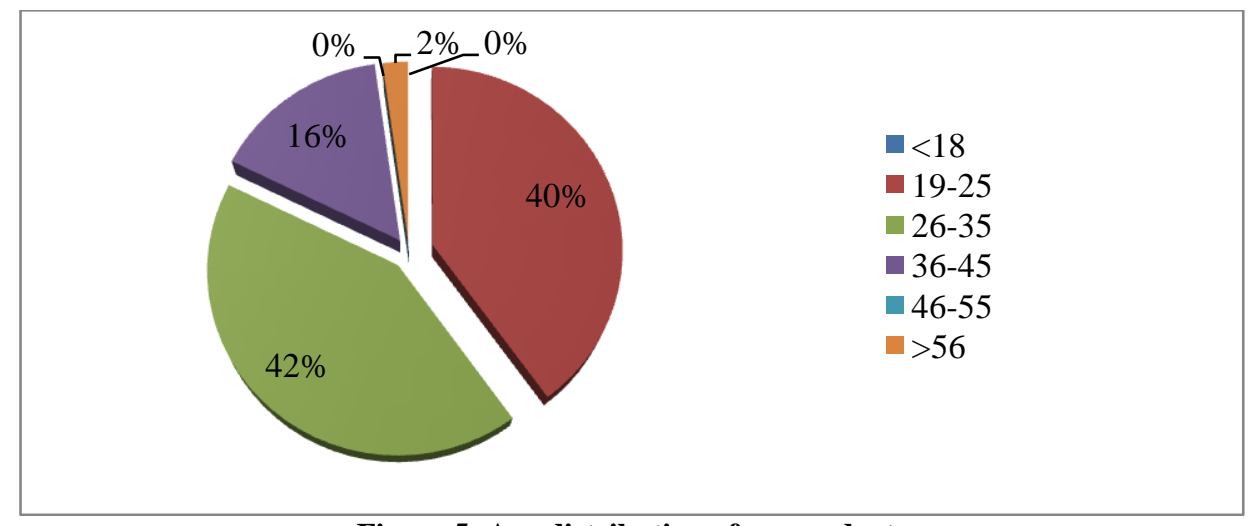

Figure 5: Age distribution of respondents 
Figure 6 graphically portrays the racial profile of the respondents who participated in the study. The majority of respondents (73\%) were black employees or owners working in small businesses in the Tshwane region. Thirteen percent consisted of Coloured respondents, and Indians, Chinese and White people each made up four percent of the sample.

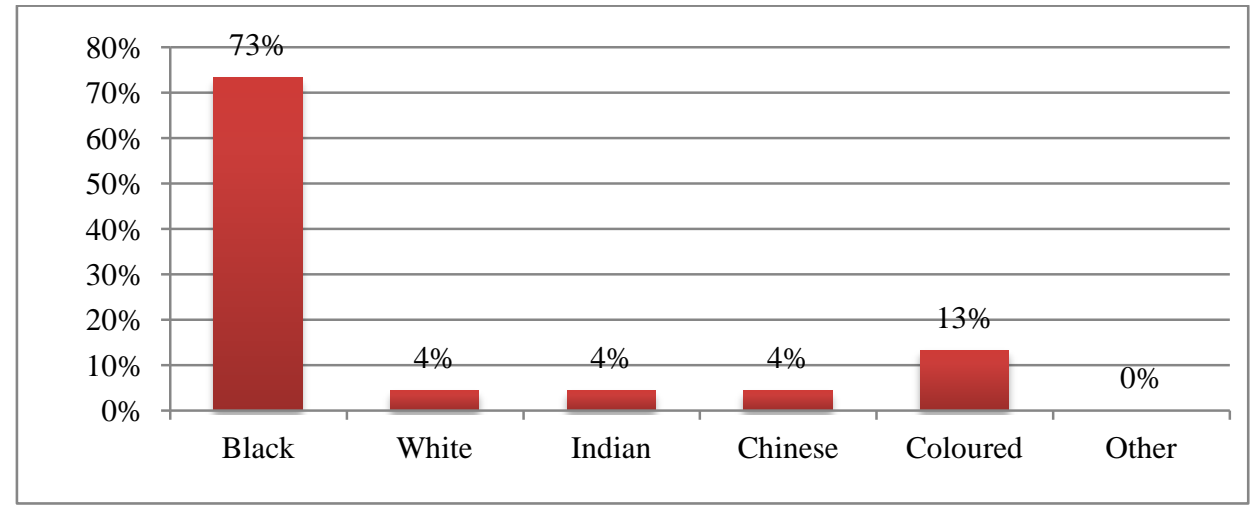

Figure 6: Racial groups

\section{RECOMMENDATIONS}

It has been emphasised that the small business sector is a great facilitator of the economy, but it is very difficult to operate in the complex and competitive business environment. However, all businesses including small businesses are under greater scrutiny from stakeholders, customers and competitors to operate ethically and therefore small businesses must ensure that they meet these expectations of these groups. The study has shown that respondents perceive it to be more important to make a profit and survive in the complex small business environment than it is to operate ethically in the work they do. This is in a way understandable given the high unemployment rate in South Africa (close to 40\%) and the example set by larger local and international companies as well as government leaders.

It is the responsibilities of management to ensure that the business has a clear, understandable and transparent code of ethics in place. Management also have to ensure that their employees are aware of this code, understand it and has access to it when needed or in doubt. In order to achieve this, management can provide training, practice examples and continuous assessment of the working environment to ensure employees are productive, but still ethical in the way they conduct business. Ensure that a clear and transparent code of ethics is set out for the organisation and that employees understand what is meant with the ethical code of conduct, what are ethical misconduct as well as the consequences thereof..

It is also crucial for the long term survival of the business to constantly evaluate the business environment of employees and management to ensure the ethical responsibility of each individual in the business. This implies a focused approach and a constant monitoring of changes in the behaviour and attitude of employees and co-workers in the business environment regarding ethics. Above all the management and owners of the business should set the example and act ethically in such a way that it becomes a way of life in the organisation.

\section{CONCLUSIONS}

The small business sector of South Africa plays an essential role in the development of South Africa's economy and has become the primary source of job creation. These small businesses are under great pressure to perform in an ethical manner. Hence, the aim of this study was to determine the attitude small business employees have towards the ethical business environment. The research formulated three objectives to establish the attitude of small business employees. The main objective of the study was to determine the attitude employees have towards the ethical responsibilities of the business. The results of this study indicate that employees of small businesses, on average, have a negative attitude towards the ethical responsibilities of the business environment. Although their attitude is fairly negative, they have a relatively good understanding of what ethics involves in the business 
environment, indicating a negative correlation between respondents understanding of ethics and their attitude towards the ethical business environment. Further research is needed to determine the attitude of employees in different regions and sectors in South Africa and to determine possible cases of misconduct by small business employees.

\section{AUTHOR INFORMATION}

Professor Michael Cant is COD Marketing and Retail Management at the university. He has published over 15 accredited articles in refereed journals and is the editor and author of more than 20 books in marketing. These books are widely prescribed at universities in South Africa. He has presented papers at more than 45 international conferences all over the world and is a well respected marketing and retail scholar. He holds a $\mathrm{PhD}$ in Marketing from the University of South Africa. E-mail: cantmc@unisa.ac.za

\section{REFERENCES}

1. Asgary, N. \& Mitschow, M.C. (2002). Towards a model for international business ethics. Journal of Business Ethics, 36(3):239-246.

2. Bageac, D., Furrer, O. \& Reynaud, E. (2011). Management student's attitude towards business ethics: a comparison between France and Romania. Journal of Business Ethics, 98(3):391-406.

3. Collins, E., Dickie, C. \& Weber, P. (2010). New Zealand and Australia: a New Zealand and Australian overview of ethics and sustainability in SMEs. The International Society of Business, Economics, and Ethics Book Series 2, 2(1):85-97.

4. $\quad$ Ferrell, O.C., Hirt, G.A. \& Ferrell, L. 2012. Business. $3^{\text {rd }}$ ed. NY: McGraw-Hill.

5. Gao, Y. (2008). An ethical judgement framework for corporate political action. Journal of Public Affairs, 8(2):153-163.

6. Gravetter, F.J. \& Wallnau, L.B. (2009). Statistics for behavioural sciences. (8th ed.). Belmont: Wadsworth.

7. Ibrahim, N., Angelidis, J. \& Tomic, I.M. 2009. Managers' attitude towards codes of ethics: are there gender differences? Journal of Business Ethics, 90(3):343-353.

8. Longenecker, J.G., Moore, C.W., Petty, J.W., Palich, L.E. \& McKinney, J.A. (2005). Ethical attitudes in small businesses and large corporations: theory and empirical findings from a tracking study spanning three decades. Retrieved from: http://www.icsb.org/documents/Ethics_WashingtonDC_Paper 05.16.05.pdf

9. Mahdavi, I. (2009). International business ethics: strategies and responsibilities. Journal of Academic \& Business Ethics, 2(Jul):1-6.

10. Price, G. \& van der Walt, J. (2012). Changes in attitude towards business ethics held by former South African business management students. Journal of Business Ethics, 107.

11. Quinn, J.J. (1997). Personal ethics and business ethics: the ethical attitudes of owner/managers of small business. Journal of Business Ethics, 16(2):119-127.

12. Raisner, J.A. (1997). Using the "ethical environment" paradigm to teach business ethics: the case of the Maquiladoras. Journal of Business Ethics, 16(14):119-127.

13. Rao, C.P. \& Vitell, S.J. (2001). How important are ethics and social responsibility? A multinational study of marketing professionals. European Journal of Marketing, 35(1/2):133-152.

14. Rossow, D. (2004). Business ethics. $3^{\text {rd }}$ ed. Southern Africa: Oxford.

15. Saunders, M., Lewis, P \& Thornhill, A. (2007). Research methods for business students. (4th ed.). Essex: Pearson Education.

16. Shakeel, M., Khan, M.M. \& Khan, M.A. (2011). Impact of culture on business ethics. Far East Journal of Psychology and Business, 3(2):59-70.

17. Shaw, W.H. (2002). Business ethics. $4^{\text {th }}$ ed. USA: Wadsworth.

18. St. James Ethical Centre. (2009). The 2009 annual business and professionals study: business ethics study. Retrieved from: http://thehub.ethics.org.au/uploads/files/EMBARGOED\%20BUS\%20ETHICS\%20STUDY\%20WEB.pdf

19. Valadez, R.M. (2011). The value proposition of small businesses: economic engines for job creation. Journal of Management and Marketing Research, 9:1-11.

20. Vitell, S.J., Dickerson, E.B. \& Festervand, T.A. (2000). Ethical problems, conflicts and beliefs of small business professionals. Journal of Business Ethics, 28(1):15-24. 
21. Wellman, C., Kruger, F. \& Mitchell, B. (2007). Research methodology. (3rd Ed.). Cape Town: Oxford University Press Southern Africa.

22. Wielicki, T. \& Arendt, L. (2010). A knowledge-driven shift in perception of ICT implementation barriers: comparative study of US and European SMEs. Journal of Information Science, 36(2):162-174.

23. World Wide Worx. (2012). Internet matters: the quiet engine of the South African economy. Retrieved from: http://www.internetmatters.co.za/report/ZA_Internet_Matters.pdf [Downloaded: 2012-06-10].

24. Yang, T. (2006). Towards an egalitarian global environmental ethics. Retrieved from: http://publishing.unesco.org/chapters/978-92-3-104039-9.pdf [Downloaded: 2012-06-07].

25. Zikmund, W.G. \& Babin, B.J. (2007). Essentials of marketing research. $3^{\text {rd }}$ ed. USA: Thomson. 
NOTES 